\title{
Testing a new surgical instrument to obtain bovine hoof biopsy samples ${ }^{1}$
}

\author{
Heloisa M.F. Mendes², Sérgio S. Rocha Júnior ${ }^{3}$, Cahuê F.R. Paz ${ }^{3}$, \\ Rodrigo C. Valadares ${ }^{2}$, Rodrigo M. Ribeiro ${ }^{3}$, David S.D. Azevedo ${ }^{4}$, \\ Anilton C. Vasconcelos ${ }^{5}$ and Rafael R. Faleiros ${ }^{6 *}$
}

\begin{abstract}
Mendes H.M.F., Rocha Júnior S.S., Paz C.F.R., Valadares R.C., Ribeiro R.M., Azevedo D.S.D., Vasconcelos A.C. \& Faleiros R.R. 2018. Testing a new surgical instrument to obtain bovine hoof biopsy samples. Pesquisa Veterinária Brasileira 38(6):1077-1084. Departamento de Clínica e Cirurgia Veterinária, Escola de Veterinária, Universidade Federal de Minas Gerais, Av. Antônio Carlos 6627, Cx. Postal 567, campus Pampulha, Belo Horizonte, MG 31270-901, Brazil. E-mail: faleirosufmg@gmail.com

The histological and molecular analysis of biopsy samples are fundamental steps for the understanding of physiopathology, diagnosis and prognosis of the diseases. However, harvest of tissue biopsies from hoof lamellar tissue is a procedure with limitations due to lack of effective surgical instruments and techniques. The aim of the current study is to develop and test in vivo a surgical instrument with the specific purpose of harvesting lamellar tissue in cattle. A prototype called Falcão-Faleiros' lamellotome (INPIBR102013018765-8) was designed, produced and tested. After sedation, five adult cattle were restrained in lateral recumbency and locally anesthetized in two digits. The stratum corneum was worn down using a rotary tool coupled to a $3 / 8$ " high-speed cutter until the soft tissue proximity was reached. Next, the inner edge of the worn area was bounded with a scalpel. The lamellotome was introduced to obtain and hold the sample. The histological specimens of $16 \mathrm{~mm}$ length by $6 \mathrm{~mm}$ depth were stained with HE, PAS, Masson's thricome and Shorr. The structures of interest were differentiated in the histological analysis without technical artifacts and a mean number of 85 epidermal laminae per sample were counted. No relevant lameness or wound complication were seen following the procedure. In conclusion the technique using the lamellotme was effective in obtaining lamellar tissue biopsy samples without causing clinical harm in cattle. The procedure showed potential to be used in clinical research or even as a supplementary diagnosis method for routine bovine podiatry.
\end{abstract}

INDEX TERMS: Surgery instrument, bovine, hoof, biopsy, claw, laminitis, cattle.

\begin{abstract}
RESUMO.- [Teste de viabilidade de um instrumento cirúrgico para obtenção de biópsias do tecido laminar do casco de bovinos.] A avaliação das propriedades histológicas
\end{abstract}

\footnotetext{
${ }^{1}$ Received on May 22, 2017.

Accepted for publication on June 15, 2017.

${ }^{2}$ Professor, Universidade Federal dos Vales do Jequitinhonha e Mucuri (UFVJM), Av. Vereador João Narciso 1380, Unaí, MG 38610-000, Brazil.

${ }^{3}$ Programa de Pós-Graduação em Ciência Animal, Universidade Federal de Minas Gerais (UFMG), Av. Antônio Carlos 6627, Cx. Postal 567, Belo Horizonte, MG 31270-901, Brazil.

${ }^{4}$ Graduado em Medicina Veterinária, Escola de Veterinária, Universidade Federal de Minas Gerais (UFMG), Av. Antônio Carlos 6627, Cx. Postal 567, Belo Horizonte, MG 31270-901.

${ }^{5}$ Professor, Instituto de Ciências Biológicas, Universidade Federal de Minas Gerais (UFMG), Av. Antônio Carlos 6627, Cx. Postal 567, Belo Horizonte, MG 31270-901.

${ }^{6}$ Professor, Escola de Veterinária, Universidade Federal de Minas Gerais (UFMG), Av. Antônio Carlos 6627, Cx. Postal 567, Belo Horizonte, MG 31270 901. *Corresponding author: faleirosufmg@gmail.com
}

e da expressão de genes e proteínas em biópsias tem sido determinante para o entendimento da fisiopatologia, o diagnóstico e o prognóstico das enfermidades. Entretanto, a obtenção de biópsias do casco é um procedimento com limitações devido à ausência de técnicas e instrumentos específicos. $\mathrm{O}$ objetivo foi desenvolver e testar, na espécie bovina, um instrumento cirúrgico especificamente desenvolvido para realização de biópsias de casco nominado lamelótomo de Falcão-Faleiros (INPI, BR102013018765-8). Utilizaram-se cinco bovinos adultos que foram sedados, contidos em decúbito lateral e tiveram dois dígitos anestesiados. Em seguida, uma serra circular acoplada a uma microretífica foi usada para o desgaste do estrato córneo na parede dorsal até próximo do estrato lamelar. Após incisões retilíneas delimitando a borda interna da área desgastada, utilizou-se o lamelótomo para obtenção da amostra. Os fragmentos de $16 \mathrm{~mm}$ de 
comprimento e $6 \mathrm{~mm}$ de profundidade foram fixados em formalina e processados para histologia com colorações HE, PAS, Shorr e tricrômico de Masson. Nenhum dos animais apresentou claudicação ou complicação relevantes no período pós-opertório. As amostras foram consideradas adequadas quanto à integridade das lâminas e à preservação de sua arquitetura. Obtiveram-se média de 85 lâminas epidérmicas viáveis por biópsia. Conclui-se que o lamelótomo de FalcãoFaleiros é apropriado e seguro para a obtenção de biópsias de casco em bovinos, se mostrando promissor para uso em estudos clínicos e na rotina de diagnóstico de problemas podais em bovinos.

TERMOS DE INDEXAÇÃO: Instrumento cirúrgico, biópsia, tecido laminar, bovinos, casco, laminite, cirurgia.

\section{INTRODUCTION}

Foot diseases are a serious issue for dairy and beef cattle breeding since they cause a strong negative economic impact on cattle industry (Silva et al. 2001, Warnick et al. 2001, Miskimins 2002, Bergsten 2003, Ferreira et al. 2004, Mauchle et al. 2008). Laminitis, which is a production disease (Mulligan \& Doherty 2008) of multifactorial origin (Greenough 2007), stands out among foot diseases since it is considered to be the main hoof disease affecting dairy cattle (Nocek 1997). However, its pathophysiology remains unclear (Thoefner et al. 2005, Randhawa et al. 2012).

Some studies about the pathophysiology of laminitis showed histological, cellular, and/or molecular changes in the hoof lamellar tissue (Nilsson 1963, Tarlton et al. 2002, Thoefner et al. 2005, Danscher et al. 2010, Mendes et al. 2012, 2013, Osorio et al. 2012). However, studies of this nature conducted in cattle remain scarce (Mgasa \& Kempson 2002), which limits the understanding of its pathophysiology. By contrast, with respect to the equine species, numerous advances have been achieved in the understanding of tissue, cellular, and molecular aspects of laminitis because of the detailed investigation of the hoof lamellar tissue. These studies examined tissue samples obtained through a biopsy (Croser \& Pollitt 2006, Paes Leme et al. 2010, Visser \& Pollitt 2011, Lima 2013) or after the euthanasia of animals (Waguespack et al. 2004, Belknap et al. 2007, Van Eps \& Pollitt 2009, De Laat et al. 2010, 2012, Paes Leme et al. 2010). The obtainment of biopsy samples has the advantage of avoiding euthanasia (Paes Leme et al. 2010) and it allows characterization of the progress of the lesions through serial tissue harvesting (Hanly et al. 2009, Singh et al. 1993).

The hoof lamellar tissue of bovines consists of dermal and epidermal laminae interspersed with each other and adheres to the stratum corneum of the hoof (König \& Liebich 2004). These laminae are supported by the underlying dermis, which is tightly attached to the distal phalanx (Van Amstel \& Shearer 2006). Thus, the dermal and epidermal laminae constitute the dermis-epidermis junction of the hoof (Greenough 2007), which is also referred to as lamellar tissue (Mgasa \& Kempson 2002).

The first report of a biopsy method to obtain lamellar tissue was described by Singh et al. (1993), who used a skin biopsy punch applied to the hoof lamellar tissue of bovines. The method, after undergoing (or without) modifications, was also used in buffaloes and horses (Singh et al. 1994,
Alves et al. 2004, Croser \& Pollitt 2006, Hanly et al. 2009, Gravena et al. 2012, Paes Leme et al. 2010, Osorio et al. 2012, Randhawa et al. 2012).

The critical point in obtaining the lamellar tissue biopsy samples is separating the dermis from the distal phalanx (Gravena et al. 2012). According to the reviewed studies, the procedure was only possible through the utilization of a combination of instruments that are commonly used in veterinary medicine or dentistry because of the lack of specific instruments for the biopsy. The modifications to the functions or applications of these instruments enable their use in harvesting lamellar tissue. Nevertheless, difficulties in separating the dermis from the distal phalanx have been reported.

Considering that a) the available methods used to perform hoof biopsies are limited, b) the pathophysiology of laminitis is unclear, and c) the effective obtainment of lamellar tissue samples may help broadening the studies about their histology and cell and molecular biology, the aim of the current study was to present a surgical instrument that has been validated in cattle and was specially developed to obtain hoof lamellar tissue biopsy samples of ungulate animals.

\section{MATERIALS AND METHODS}

Ethic statement. The current study was approved by the Ethics Committee on Animal Use (CEUA no.286/2013) of the Universidade Federal de Minas Gerais (UFMG).

Animals. Five male adult animals were used in the current study (Girolando cattle, $n=4$, and Holstein cattle, $n=1$ ). The weight of the animals ranged from 355 to $576 \mathrm{~kg}$. Two of them were castrated and the other three were not; they were adapted to stalls and were fed diets based on hay $(n=4)$ orchopped cane $(n=1)$ for 15 days. Biopsies were simultaneously performed in one forelimb (medialclaw) and in one hindlimb (lateral claw). The animals were evaluated for lameness 15 days after the biopsy, according to the scoring system described by Sprecher et al. (1997).

Performing the biopsies. After the animals were subjected to a liquid diet for 24 hours, they were sedated with intra muscularly administered xylazine $(0.04 \mathrm{mg} / \mathrm{kg})$ combined with acepromazine $(0.04 \mathrm{mg} / \mathrm{kg})$ and then held inlateral recumbency. Their limbs were anesthetized with $2 \%$ lidocaine without a vasoconstrictor using the three-point technique described by Salomon \& Geyer (2006). In the procedure, the needle was introduced transversely into the subcutaneous tissue $1.5 \mathrm{~cm}$ from the proximal metacarpophalangeal joint in order to block the dorsal (dorsally), medial palmar (medially), and lateral palmar (laterally) nerves. A tourniquet was applied to the middle third of the metacarpal/metatarsal region after antisepsis in order to minimize bleeding during the biopsy.

An instrument specifically designed to obtain the hoof lamellar tissue samples, called Falcão-Faleiros' lamellotome (INPI - National Institute of Industrial Property, Brazil BR102013018765-8), was used. It consists of a rod with a handle at one end and an active tip for laminar tissue removal at the other end, as shown in Figure 1. The active tip consists of three surfaces, namely one floor and two sidewalls; each of them has acutting edge at the end. The active tip was designed to disconnect the lamellar tissue sample close to the distal phalanx while preserving the deep dermisand without compromising the lamellar architecture.

The biopsy was performed in three steps: 1) wearing down of the stratum corneum; 2) defining the biopsy site; 3) obtaining the lamellar tissue biopsy sample (Fig.2). A micro-rectifier-typerotary 


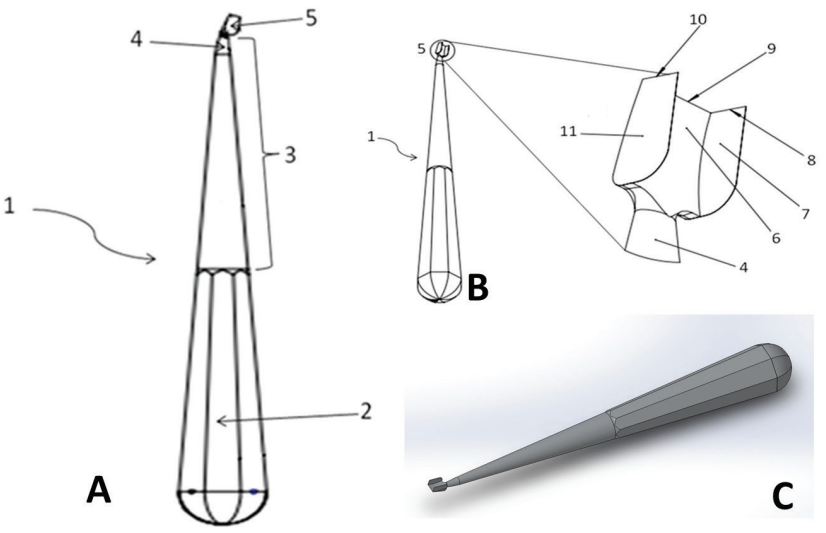

Fig.1. Surgical instrument called Falcão-Faleiros lamellotome used to perform hoof biopsies "on ungulate animals". (A) Surgical instrument (1), handle (2), rod (3), rod curvature (4), active tip 95). (B) Active tip floor (6), sidewalls (7 and 11), cutting edges of the walls (8 and 10), cutting edge of the floor (9). (C) 3D image of the instrument.

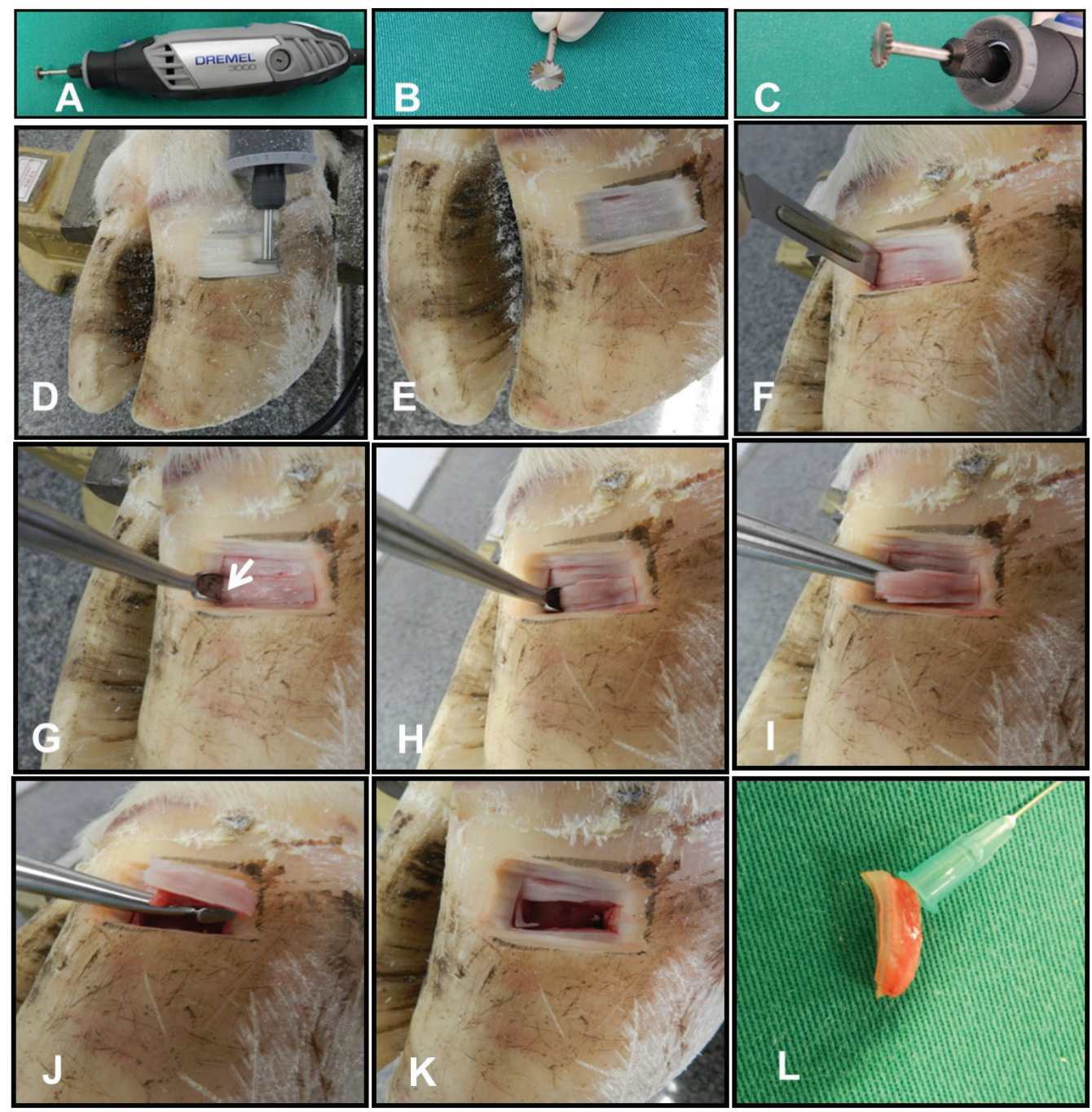

Fig.2. Steps of the hoof lamellar tissue biopsy procedures in anatomical specimen using the Falcão-Faleiros lamellotome. (A) Micro-rectifier-type rotary tool (Dremel). (B) 3/8" high-speed cutter (Dremel). (C) Detail of the tool coupled with the high-speed cutter. (D,E) Wearing of the stratum corneum of the hoof in anatomical specimen through horizontal rectilinear movements of the Dremel/high-speed cutter assembly. (F) Incision lines performed around the worn area. (G) Vertical positioning of the instrument with the active tip guided towards the incision lines. (H) Introduction of the lamellotome towards the distal phalanx. (I,J) Lamellotome horizontally guided, after changing the direction of its rod. (K) Final aspect of the biopsy site after the tissue specimen removal. (L) Obtained tissue specimen. 

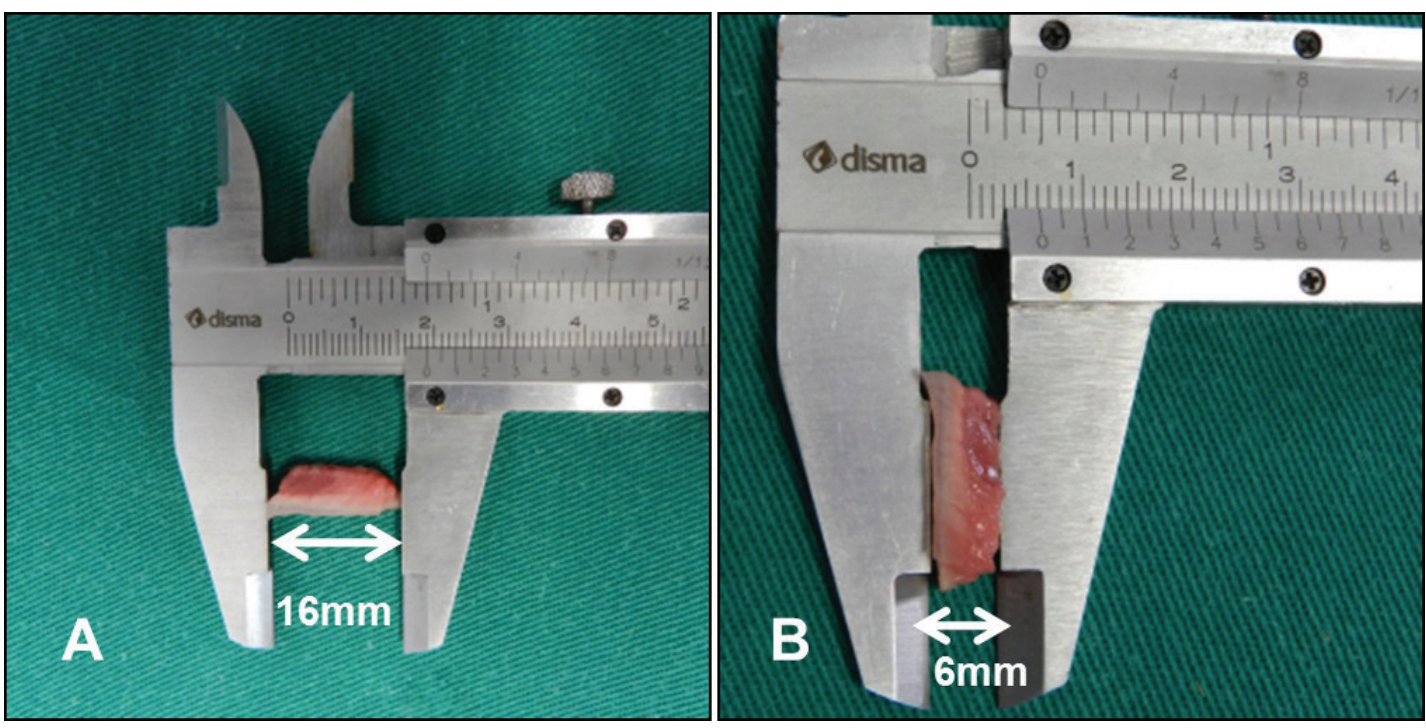

Fig.3. Lamellar tissue specimen showing (A) length and (B) depth.

tool (Dremel) coupled to a 3/8" high-speed cutter (Dremel) was used in step 1 . The Dremel/high-speed cutter assembly performed rectilinear movements in the dorsal hoof wall, approximately $2 \mathrm{~cm}$ distal to the coronary band and lateral to the interdigital cleft. The stratum corneum was worn down until the soft tissue was noticeable through palpation with hypodermic needle. With respect to step 2, the biopsy site was delimited using a scalpel coupled to a blade no.11 or 20. Incisions were performed in the lamellar tissue following the inner edges of the area worn in step 1 . As for step 3 , the surgical instrument was introduced in the performed incision lines and the active tip was vertically guided until it reached the distal phalanx. Subsequently, the instrument handle was diagonally moved so that the active tip could slide parallel and close to the phalanx surface until it removed the specimen (Fig.3). There was moderate bleeding after the biopsy sample collection due to application of the tourniquet prior to the sampling procedure. The biopsy site was covered with an autopolymerizing acrylic, which was kept attached to the hoof with a bandage for two days. After the bandage was removed, $10 \%$ iodine was topically applied to the wound site. The animals received enrofloxacin $(2.5 \mathrm{mg} / \mathrm{kg})$ and meloxicam $(0.5 \mathrm{mg} / \mathrm{kg})$, which were intra muscularly administered for three consecutive days. Lameness was evaluated, according to the scoring system of Sprecher et al. (1997), when the animals were handled during placement of the bandages. A single animal had level-3 lameness for five days, which required the extension of the anti-inflammatory treatment.

Histology. The specimens were fixed in 4\% formaldehyde, buffered, for 48 hours, histologically processed, and embedded in paraffin blocks. Five-micrometer histological sections were stained with hematoxylin and eosin (HE), periodic acid-Schiff (PAS), and Shorr and Masson's trichrome. The number of viabledermal/epidermal laminae was counted in PAS staining, and the laminae that were intact from the abaxial to the axial region were considered to be viable.

\section{RESULTS}

The sedation and anesthesia protocol enabled the procedure to be performed without risks to the animal orto the professionals, with a recumbency time of approximately 40 minutes to handle two claws.

The wear of the stratum corneum using the micro-rectifier coupled to a high-speed cutter allowed rapid and satisfactory access to the underlying soft tissue. The incision lines were made with the scalpel to reduce the resistance of the remaining stratum corneum tissue during the lamellotome insertion in the lamellar tissue. The maneuvers performed with the instrument were considered effective, fast, and simple when performed by two different users.

A single animal had lameness (grade 3) the day after the surgery, and it lasted for five days. The other animals $(n=4)$ showed no lameness or signs of discomfort. There were no wound complications after the bandage was removed. After 40 days, the biopsy site was covered by keratinized tissue in the two handled claws of one animal and by granulation tissue in another animal.

The number of epidermal laminae obtained from each animal is shown in Table 1. The dimensions of the histological sections were satisfactory regarding the length of the lamellar tissue and the depth of the obtained dermis, as shown in

Table 1. Number of dermal/epidermal laminae obtained from cattle using the Falcão-Faleiros lamelotom

\begin{tabular}{ccc}
\hline \multirow{2}{*}{ Animal } & \multicolumn{2}{c}{ Number of viable laminae } \\
\cline { 2 - 3 } & Forelimb & Hindlimb \\
\hline 1 & 54 & 78 \\
2 & 43 & 65 \\
3 & 90 & 47 \\
4 & $141^{*}$ & $174^{*}$ \\
5 & $103^{*}$ & $50^{*}$ \\
Mean & 86 & 83 \\
SD & 39 & 52
\end{tabular}

* The variation between the number of laminae and the mean observed in these animals regards the fact that their laminae were morphologically similar to the papilla in the foot sole. 


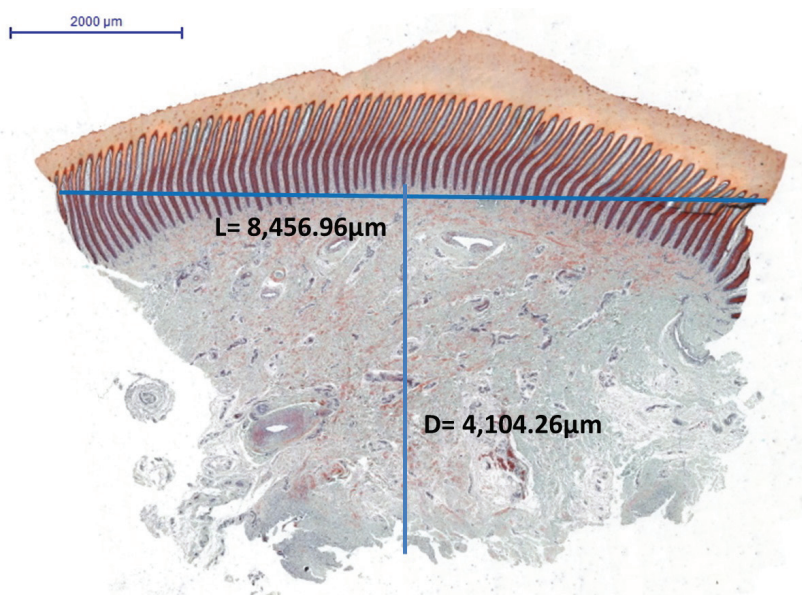

Fig.4. Shorr-stained histological specimen showing the length (L) of the lamellar tissue and the depth (D) of the obtained dermis. The biopsy sample comes from the hindlimb of the animal 2 in Table 1.
Figure 4. There was slight variation in the length and depth of the biopsy samples.

The tissue features were preserved. HE, PAS, and Shorrand Masson's trichome stains enabled clear and uniform disclosure of the histological features of the lamellar tissue, that is, clear distinction of the remaining stratum corneum, dermal and epidermal laminae layer, and the dermal layer. The nuclei of the epidermal and dermal cells, extra cellular matrix, basal membrane, and the keratinized axis of the laminae were histologically differentiated in a proper way. The tissue architecture appeared to be normal and preserved. The PAS staining could distinguish the basal membrane and the nuclei of the epidermal laminae. The Masson's trichrome staining could distinguish the keratinizedaxis (red) of the epidermal laminae and the connective tissue (blue) of the dermis. The laminae showed no distortion or fracture that could compromise the histological quality (Fig.5).
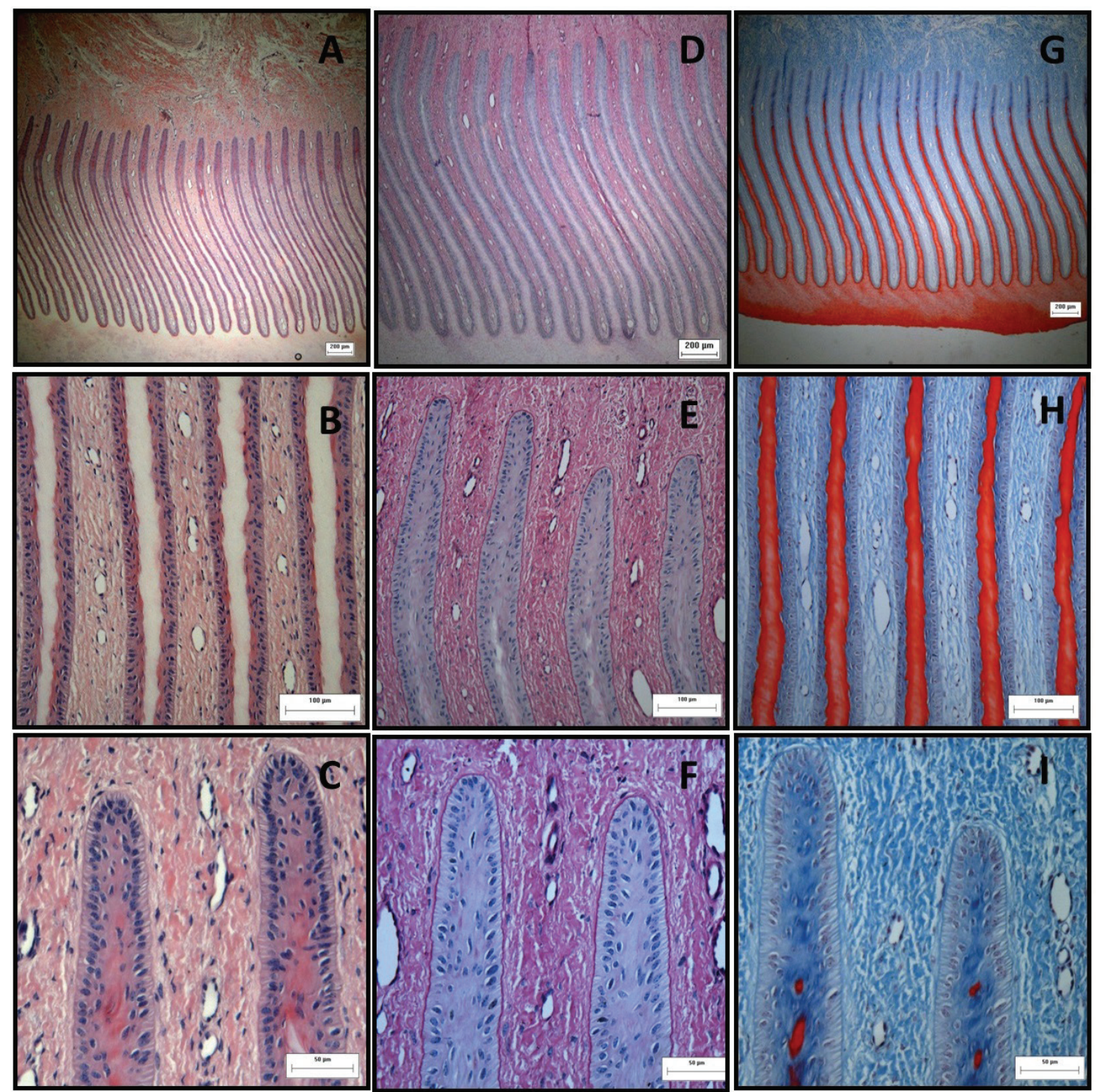

Fig.5. Histology of cattle hoof laminae obtained through biopsy using the Falcão-Faleiros lamellotome. (A-C) HE staining, (D-F) PAS staining,

(G-I) Masson's thricome staining. Bars in A, D and G $=200 \mu \mathrm{m}$; bars in B, E and H $=100 \mu \mathrm{m}$; bars in C, F and I $=50 \mu \mathrm{m}$. 


\section{DISCUSSION}

The stratum corneum was worn in order to get as close to the lamellar tissue as possible and to eliminate the resistance of the keratinized layer to the surgical instrument. Therefore, it was necessary to perform this procedure before using the Falcão-Faleiros' lamellotome, and it constitutes part of the biopsy technique presented in the current study.

Most of the reviewed studies used drills with different diameters coupled to a drilling machine to wear the stratum corneum (Singh et al. 1993, 1994, Croser \& Pollitt 2006, Hanly et al. 2009, Randhawa et al. 2012, Osorio et al. 2012). Other studies used trimming tools such as roof rasps and hoof knives in the same procedure (Alves et al. 2004, Paes Leme et al. 2010). On the other hand, Gravena et al. (2012) used a microrectifier coupled to a grinding stone. The present study used a micro-rectifier coupled to a high-speed cutter. This dorsal wall wearing method proved to be better than the useof a drill or grinder. Such methods only produced a circular hole in the stratum corneum of the hoof, thus limiting the size of the biopsy samples to the diameter of the accessories (Singh et al. 1993, 1994, Croser \& Pollitt 2006, Hanly et al. 2009, Randhawa et al. 2012, Osorio et al. 2012). On the other hand, the high-speed cutter had the advantage of wearing the stratum corneum in flat shapes such as rectangles or squares of variable sizes; thus, it was possible to choose the size of the biopsy specimen to be remove dusing the proposed surgical instrument. The method used in the present study also has an advantage over the use of hoof rasps and hoof knives, because it demands less effort, and it is faster and more accurate. The micro-rectifier/high-speed cutter assembly allowed quick and easy wearing of the stratum corneum using minimum effort, thus giving agility to the process and reducing the biopsy time in comparison to the other available methods.

The proximity of the soft tissue could be verified during the wearing process through the emergence of a pinkish shade on the surface of the worn area, which indicated the presence of vascularized tissue (Singh et al. 1993). In case of any doubt about the proximity of this tissue, an alternative test could be performed by using a disposable needle to verify the dullness of the area.

The incisions performed with the scalpel effectively delimited the biopsy specimen and reduced the tissue resistance to the lamellotome during its insertion. The other studies did not perform this procedure since they used a skin biopsy punch to obtain the specimens (Singh et al. 1993, 1994, Alves et al. 2004, Croser \& Pollitt 2006, Hanly et al. 2009, Paes Leme et al. 2010, Randhawa et al. 2012, Osorio et al. 2012).

The most critical point in obtaining the lamellar tissue biopsy samples is separating the dermis from the distal phalanx (Gravena et al. 2012) because of the large amount of collagen fibers in the dermis (Greenough 2007). There viewed studies used scalpel blade (Hanly et al. 2009), scalpel blade curved by heating (Croser \& Pollitt 2006), skin biopsy punch (Singh et al. 1993, 1994, Alves et al. 2004, Hanly et al. 2009, Paes Leme et al. 2010, Randhawa et al. 2012, Osorio et al. 2012) or Frahm carver no.2 (Gravena et al. 2012) to separate them. Thus, it was necessary to redefine the maneuvers and/or exchange the instrument to achieve the goal. In contrast, the use of the proposed instrument allowed acquisition of the biopsy samples in a single and uninterrupted sequence of movements, which effectively separated the dermis from the distal phalanx. Hanly et al. (2009) reported that the skin biopsy punch failed to separate the dermis from the phalanx, and that is was necessary to resort to the scalpel blade. Gravena et al. (2012) used a dental instrument called Frahm carver no. 2 to separate the dermis from the distal phalanx in horses. However, it was necessary to resort to a dissecting clamp and to a Halsted hemostatic clamp to complete the procedure. Croser \& Pollitt (2006) opted for heat-bending of as scalpel and subsequently introducing it into the biopsy site to separate the dermis from the distal phalanx of horses. According to the experience of our research group, there was quick rupture of the blade after it was heated and it was also difficult to insert it into the biopsy site. Gravena et al. (2012) also considered this unviable alternative. Osorio et al. (2012) used a scalpel blade and dissection clamp to separate the dermis from the distal phalanx in cattle, as a modification to the method by Singh et al. (1993). None of these modifications were necessary when the Falcão-Faleiros' lamellotome was used because the cutting edge of the active pit floor (Fig.1B9) was effective in cutting the dermis and separating it from the distal phalanx. It was essential to guide the instrument close to the phalanx in order to obtain the largest area of dermis possible (Fig.4). Therefore, the main difference of the proposed instrument is that can be used in a single and uninterrupted sequence of maneuvers and it provides outstanding performance in separating the dermis from the distal phalanx as it was especially developed to obtain hoof biopsy specimens.

The length of the specimens changed from animal to animal; however, they were all considered satisfactory in view of the number of obtained laminae. Osorio et al. (2012) obtained small specimens of approximately $9 \mathrm{~mm}$ for molecular biology studies of the hoof. No study about lamellar tissue histology obtained by skin biopsy punchin cattle was found. Gravena et al. (2012) obtained 9mm-long samples for histology studies involving optical and electron microscopyin horses. Larger specimens are desirable, especially in hoof histology studies, because they provide a greater tissue area to be analyzed. Thus, both the high-speed cutter and the Falcão-Faleiros' lamellotome permit acquisition of a sample size of any desired dimensions when a smaller or larger specimen is needed.

The histological evaluation showed that the tissue structures of the specimens removed by the Falcão-Faleiros' lamellotome were preserved. Thus, normal histological disclosure of the lamellar tissue was possible, as mentioned in histological studies of bovine specimens (Nilsson 1963, Tarlton et al. 2002, Thoefner et al. 2005, Danscher et al. 2010, Mendes et al. 2013).

The obtained tissue specimens showed a mean number of viable laminae of $86 \pm 39$ in the forelimb and $83 \pm 52$ in the hindlimb. These values were higher than those reported in studies that used a skin biopsy punch in equine species, in which specimens with dimensions of $7 \times 5 \mathrm{~mm}$ were obtained, with each of them showing 8 to 12 primary epidermal laminae (Gravena et al. 2012). It is worth emphasizing that larger specimens can be easily obtained using the proposed method because of the features of the rectangular wear of the hoof wall and those of the lamellotome.

Two animals had changed epidermal laminae, and their shape was similar to that of the papillae in the foot sole, a fact that led to an increased number of recorded laminae (Table 1). However, this change was not caused by the surgical 
instrument and/or technique, and it was considered to be intrinsic to the sampled animals.

Approximately $1 / 3$ of the length of the specimens obtained in the current study was used in molecular biology studies. Thus, the obtained number of laminae is small in relation to the size of the specimen itself. Therefore, specimens of up to $12 \mathrm{~mm}$ in length provide a satisfactory amount of laminae without resulting in animal claudication.

The presence of distortions or fractures in the epidermal and dermal laminae that are biopsy technique-related artifacts was another histologically evaluated criterion. Laminae distortions were observed in the study by Osorio et al. (2012), who used the skin biopsy punch. However, the present study detected no technique-related artifacts.

Croser \& Pollitt (2006) reported moderate lameness in some horses after the biopsies; however, the procedure was considered to be well tolerated. The impact of the biopsies on the animals was considered to have little clinical relevance in the current study, since four out of five animals showed no lameness. Only one animal showed lameness after the biopsy and this was attributed to a failure in the anesthetic block during the biopsy and to possible inexperience, since it was the first tested animal. The reemergence of keratinized tissue at the biopsy site in one animal 40 days later suggests rapid recovery of the wounded tissue.

\section{CONCLUSIONS}

It was concluded that the Falcão-Faleiros' lamellotome is suitable for obtaining cattle hoof lamellar tissue biopsy samples because a sufficient number of samples of satisfactory histological quality could be obtained without causing harm to the animals.

The lamellotome showed significant potential for use in veterinary podiatry research and it may contribute to enhancement of knowledge in this field.

In addition, the instrument can be used in the routine diagnosis of cattle foot problems.

Conflict of interest statement.- The authors have no competing interests.

Acknowledgements.- To CAPES, CNPq and FAPEMIG for financial support. To Celina Oliveira for technical support.

\section{REFERENCES}

Alves G.E.S., Paes Leme F.O., Marval C.A., Bonna F.A.B., Xavier S.H.N., Faleiros R.R. \& Santos R.L. 2004. Biópsia digital em equinos com laminite induzida por sobrecarga de carboidratos. Braz. J. Vet. Res. Anim. Sci. 41(Suppl. ):264-265.

Belknap J.K., Giguère S., Pettigrew A., Cochran A.M., Eps A.W. \& Pollitt C.C. 2007. Lamellar pro-inflammatory cytokine expression patterns in laminitis at the developmental stage and at the onset of lameness: innate vs. adaptive immune response. Equine Vet. J. 39(1):42-47. http://dx.doi. org/10.2746/042516407X155406. PMid:17228594.

Bergsten C. 2003. Causes, risk factors, and prevention of laminitis and related claw lesions. Acta Vet. Scand. 98(Suppl.):157-166. http://dx.doi. org/10.1186/1751-0147-44-S1-S157. PMid:15259788.

Croser E.L. \& Pollitt C.C. 2006. Acute laminitis: descriptive evaluation of serial hoof biopsies. Proc. 52nd Annual Convention of the American Association of Equine Practitioners, San Antonio, Texas, p.542-546.

Danscher A.M., Toelboell T.H. \& Wattle 0. 2010. Biomechanics and histology of bovine claw suspensory tissue in early acute laminitis. J. Dairy Sci. 93(1):53-62. http://dx.doi.org/10.3168/jds.2009-2038. PMid:20059904.
De Laat M.A., McGowan C.M., Sillence M.N. \& Pollitt C.C. 2010. Equine laminitis: induced by $48 \mathrm{~h}$ hyperinsulinaemia in Standardbred horses. Equine Vet. J. 42(2):129-135. http://dx.doi.org/10.2746/042516409X475779. PMid:20156248.

De Laat M.A., Sillence M.N., McGowan C.M. \& Pollitt C.C. 2012. Continuous intravenous infusion of glucose induces endogenous hyperinsulinaemia and lamellar histopathology in Standardbred horses. Vet. J.191(3):317-322. http://dx.doi.org/10.1016/j.tvjl.2011.07.007. PMid:21873088.

Ferreira P.M., Leite R.C., Carvalho A.U., Facury Filho E.J., Souza R.C. \& Ferreira M.G. 2004. Results and costs of treatment for bovine laminitis sequelae: study of 112 lameness cases in lactating cows in free-stall system. Arq. Bras. Med. Vet. Zootec. 56(5):589-594. http://dx.doi.org/10.1590/S010209352004000500004

Gravena K., Sampaio R.C.L., Dias D.P.M., Canola P.A., Peiró J.R. \& Lacerda-Neto J.C. 2012. Evaluation of the integrity of horse hoof dermal and epidermal tissues collected by dorsal transmural. J. Equine Vet. Sci. 32(12):858-862. http://dx.doi.org/10.1016/j.jevs.2012.03.018.

Greenough P.R. 2007. Bovine Laminitis and Lameness: a Hands-on Approach. Elsevier, Philadelphia. 311p.

Hanly B.K., Stokes A.M., Bell A.M., Johnson J.R., Keowen M.L., Paulsen D.B., Sod G.A. \& Moore R.M. 2009. Use of serial lamelar tissue collection via biopsy in conscious healthy horses. Am. J. Vet. Res. 70(6):697-702. http://dx.doi. org/10.2460/ajvr.70.6.697. PMid:19496657.

König H.E. \& Liebich H. 2004. Anatomia dos Animais Domésticos: texto e atlas colorido. Vol.2. Artmed, Porto Alegre, p.175-177.

Lima L.R. 2013. Reparixina, um antagonista de CXCR1 e CXCR2, na laminite experimental de equinos. Tese de Doutorado, Escola de Veterinária Universidade Federal de Minas Gerais, Belo Horizonte. 62p.

Mauchle U., Carvalho A.U., Alzamora Filho F., Ferreira P.M., Facury Filho E.J \& Cavalcante M.P. 2008. Efeito da sazonalidade sobre a ocorrência de lesões podais em vacas leiteiras. Revta Bras. Saúde. Prod. Anim. 9:109-116.

Mendes H.M.F., Ferreira P.M., Alves G.E.S., Zambelli B.L., Lima I.R., Vasconcelos A.C. \& Faleiros R.R. 2012. Presence of macrophages in the hoof dermoepidermal junction in dairy cows with and without clinical signs associate to laminitis. XXVII World Buiatrics Congress, Lisboa, Portugal. (Resumo)

Mendes H.M.F., Casagrande F.P., Lima I.R., Souza C.H., Gontijo L.D., Alves G.E.S., Vasconcelos A.C. \& Faleiros R.R. 2013. Histopathology of dairy cows' hooves with signs of naturally acquired laminitis. Pesq. Vet. Bras. 33(5):613-619. http://dx.doi.org/10.1590/S0100-736X2013000500011.

Mgasa M.N. \& Kempson S.A. 2002. Functional anatomy of the lamelar region of normal bovine claws. Proc. 12th International Symposium on Lameness in Ruminants, Orlando, Florida, USA, p.180-183.

Miskimins D. 2002. Predominant causes of lameness in feedlot lameness and stocker cattle. Proc. 12th International on Lameness in Ruminants, Orlando, Florida, USA, p.147-151.

Mulligan F.J. \& Doherty M.L. 2008. Production diseases of the transition cow. Vet. J. 176(1):3-9. http://dx.doi.org/10.1016/j.tvjl.2007.12.018. PMid:18342556.

Nilsson S.A. 1963. Clinical, morphological, and experimental studies of laminitis in cattle. Acta Vet. Scand. 4(Suppl.1):1-304.

Nocek J.E. 1997. Bovine acidosis: implications on laminitis. J. Dairy Sci. 80(5):1005-1028. http://dx.doi.org/10.3168/jds.S0022-0302(97)760260. PMid:9178142.

Osorio J.S., Fraser B.C., Graugnard D.E., Singh S.S., Drackley J.K., Garrett E.F. \& Loor J.J. 2012. Corium tissue expression of genes associated with inflammation oxidative stress, and keratin formation in relation to lameness in dairy cows. J. Dairy Sci. 95(11):6388-6396. http://dx.doi.org/10.3168/ jds.2011-5143. PMid:22959934. 
Paes Leme F.O., Bonna F.A.B., De Marval C.A., Xavier S.H.N., Santos R.L., Faleiros R.R. \& Alves G.E.S. 2010. Histopatologia das laminas do casco de equinos com laminate aguda induzida e tratados com ketoprofeno, fenilbutazona e flunixin meglumine. Arq. Bras. Med. Vet. Zootec. 62(2):241-250. http:// dx.doi.org/10.1590/S0102-09352010000200001.

Randhawa S.S., Dua K., Banga H.S., Singh S.S. \& Malhotra P. 2012. Arteriosclerosis in buffalo hooves: an age related change or a pathology of lameness? Indian J. Anim. Sci. 82(7):697-701.

Salomon F.V. \& Geyer H. 2006. Atlas de Anatomia Aplicada dos Animais Domésticos. 2a ed. Guanabara Koogan, Rio de Janeiro. 254p.

Silva L.A.F., Silva L.M., Romani A.F., Rabelo R.E., Fioravanti M.C.S., Souza T.M. \& Silva C.A. 2001. Características clínicas e epidemiológicos das enfermidades podais em vacas lactantes do município de Orizona/GO. Ciênc. Anim. Bras. 2:119-126.

Singh S.S., Ward W.R. \& Murray R.D. 1993. Technique of hoof biopsy in cattle. Vet. Rec. 133(8):190-191. http://dx.doi.org/10.1136/vr.133.8.190. PMid:8236718.

Singh S.S., Murray R.D. \& Ward W.R. 1994. Gross and histopathological study of endotoxin-induced hoof lesions in cattle. J. Comp. Pathol. 110(2):103115. http://dx.doi.org/10.1016/S0021-9975(08)80182-X. PMid:8040378.

Sprecher D.J., Hostetler D.E. \& Kaneene J.B. 1997. A lameness scoring system that uses posture and gait to predict dairy cattle reproductive performance. Theriogenology 47(6):1179-1187. http://dx.doi.org/10.1016/S0093691X(97)00098-8. PMid:16728067.
Tarlton J.F., Holah D.E., Evans K.M., Jones S., Pearson G.R. \& Webster A.J.F. 2002. Biomechanical and histopathological changes in the support structures of bovine hooves around the time of first calving. Vet. J. 163(2):196-204. http://dx.doi.org/10.1053/tvjl.2001.0651. PMid:12093195.

Thoefner M.B., Wattle O., Pollitt C.C., French K.R. \& Nielsen S.S. 2005. Histopathology of oligofructose-induced acute laminitis in heifers. J. Dairy Sci. 88(8):2774-2782. http://dx.doi.org/10.3168/jds.S00220302(05)72957-X. PMid:16027191.

Van Amstel S. \& Shearer J. 2006. Manual for treatment and control of lameness in cattle. Blackwell Publishing, New Jersey. 212p. http://dx.doi. org/10.1002/9780470344576.

Van Eps A.W. \& Pollitt C.C. 2009. Equine laminitis model: lamellar histopathology seven days after induction with oligofructose. Equine Vet. J. 41(8):735740. http://dx.doi.org/10.2746/042516409X444953. PMid:20095219.

Visser M.B. \& Pollitt C.C. 2011. The timeline of lamellar basement membrane changes during equine laminitis development. Equine Vet. J. 43(4):471-477. http://dx.doi.org/10.1111/j.2042-3306.2010.00292.x. PMid:21496071.

Waguespack R.W., Kemppainen R.J., Cochran A., Lin H.C. \& Belknap J.K. 2004. Increased expression of MAIL, a cytokine-associated nuclear protein, in the prodromal stage of black walnut-induced laminitis. Equine Vet. J. 36(3):285291. http://dx.doi.org/10.2746/0425164044877099. PMid:15147139.

Warnick L.D., Janssen D., Guard C.L. \& Gröhn Y.T. 2001. The effect of lameness on milk production in dairy cows. J. Dairy Sci. 84(9):1988-1997. http:// dx.doi.org/10.3168/jds.S0022-0302(01)74642-5. PMid:11573778. 